\title{
Performance Analysis of Combined Cycle System Driven by Solid Oxide Fuel Cell
}

\author{
H.B. Zhao \\ College of Mechanical and Transportation Engineering \\ China University of Petroleum-Beijing \\ China
}

Q. Yang

College of Mechanical and Transportation Engineering China University of Petroleum-Beijing China

\begin{abstract}
Solid oxide fuel cells can directly convert chemical energy of fuel into electricity, not limited by Carnot cycle, can greatly improve efficiency. GT-Kalina combined cycle system driven by SOFC can realize the cascade utilization of the exhaust heat, by this way to improve system efficiency. This paper based on the SOFC-GT-Kalina system as the research object, using Aspen Plus to establish the process simulation, also analyzed the effects of main parameters on the performance of the system, in this way to provide guidance for system optimization and economic operation. By analysis, the integrated system has high electrical efficiency, increase the pressure ratio, ST inlet pressure and ammonia concentration appropriately can improve the system performance.
\end{abstract}

Keywords-SOFC; Kalina cycle; combined cycle; aspen plus

\section{INTRODUCTION}

As a worldwide promoted fuel cell technology in 21 st century, it has a lot of advantages. As the SOFC is not limited by Carnot cycle, its electrical efficiency can be greatly improved, even can reach $40 \%-80 \%[1]$; The high-temperature exhaust gas from SOFC still has a great deal of waste heat, using integrated power generation system to make full use of the waste heat[2] can greatly improve the energy utilization and reduce the pollutant emissions of NOx and COx. In recent years, integrated systems driven by SOFC also get rapid development.

There have been a large number of theoretical researches about integrated system driven by SOFC. Komatsu Y et al presented a thermodynamic performance analysis of ordinary top-loop type SOFC-GT integrated system at half-condition[3]; Alexandros A made further research on the basis of previous studies[4], he used waste heat boiler for heat recovery of SOFC-GT exhaust gas, in this way to generate steam to drive a ST, by analyzing he proved that the efficiency of SOFC-GT-ST integrated system can get $73.8 \%$; To modify SOFC-GT system, Zhang Jian et al [5]took SWP pressurized SOFC- GT as an example, and analyzed the principle and present situation of the SOFC-GT system, this provided reference for integrated system in our country; Song Juxing et al simulated the SOFC-GT integrated system by MATLAB[6], concluding that the efficiency of this type of integrated cycle can get more than $60 \%$ efficiency in the condition of less than $300 \mathrm{~kW}$ power.

\author{
T. Jiang \\ College of Mechanical and Transportation Engineering \\ China University of Petroleum-Beijing \\ China \\ W. Yang \\ College of Mechanical and Transportation Engineering \\ China University of Petroleum-Beijing \\ China
}

Kalina cycle[7] is a new kind of power generation system using ammonia- water mixture as working medium, as ammonia-water mixture has the advantage of variable temperature evaporation, in the heat exchange process, temperature can be better matched and can reduce the temperature difference. Combined cycle can use Kalina cycle as a bottom cycle to improve its efficiency.

\section{THE PROCESS OF THE SOFC-GT-KALINA COMBINED} CYCLE

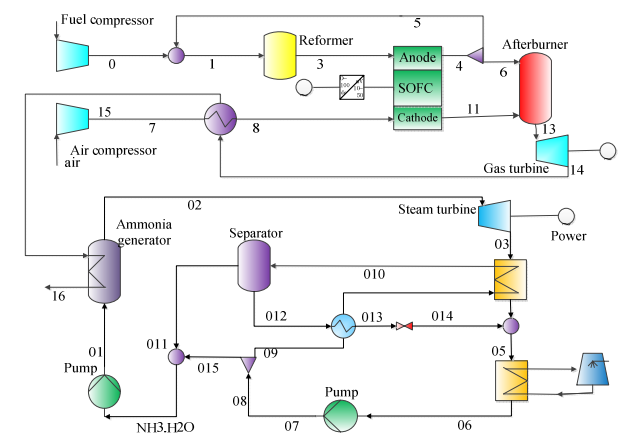

FIGURE I. THE FLOW CHART OF THE SOFC-GT-KALINA COMBINED CYCLE

In the SOFC-GT-Kalina combined system, it makes full use of the high heat in the fuel and low heat in the tail gas, fully embodies the principle of energy using according to the quality, in this way to improve the overall efficiency. Figure 1 illustrates the integrated system using in this article. After being compressed, the flue gas is fed to the anode, air is fed to the cathode after being compressed and reheated by the exhaust gas of GT, oxygen is dissociated into oxygen ions at the cathode surface, then get to the anode through the electrolyte, fuel and oxygen ions produce electricity by electrochemical reaction. After the electrochemical reaction finished, most of the excess air out of the cathode and the unreacted fuel out of the anode combust completely in the after-burner to generate electricity at GT, part of the gas recycle to the fuel preforming unit to supply water and heat for the endothermic steam reforming. Using a gas turbine for power recovery to produce electricity, then the exhaust gas from GT is sequentially used to preheat the air, then flow into Kalina cycle for further using. 
For the relevant parameters and the structure size of cell involved in the process simulation, in accordance with SWP company design.

\section{THE MATHEMATICAL MODEL OF THE SOFC}

A The Current Density Model of SOFC

The current density model of SOFC is shown in eqn. (1):

$$
I=\frac{n \cdot F \cdot 4 q_{\mathrm{CH}_{4}}}{N \cdot A}
$$

Where $\mathrm{F}$ is the Faraday constant, taking $96485 \mathrm{C} / \mathrm{mol}$; $q_{\mathrm{CH}_{4}}$ is the methane molar flow participating in the reaction; $\mathrm{N}$ is cell number; $\mathrm{A}$ is single-cell area.

\section{B The Voltage Model of SOFC}

Firstly, select the reference voltage, and then by calculating the influence of pressure, temperature, gas pressure on the voltage at the other non-reference state to calculate voltage value.

1) Influence of the operating pressure of the stack on voltage: The influence of operating pressure on the voltage is as the eqn. (2)below:

$$
\Delta V_{\mathrm{p}}(\mathrm{mV})=C_{1} \log \left(p / p_{\text {ref }}\right)
$$

Where $\mathrm{p}$ is the operating pressure of the SOFC; $p_{\text {ref }}=1$ bar; $\mathrm{C} 1=76$.

2) Influence of the operating temperature on voltage: Due to the voltage can be influence by operating temperature and current density, using eqn. (3) to describe the effect is more appropriate:

$$
\Delta V_{\mathrm{T}}(\mathrm{mV})=K .\left(T-T_{\text {ref }}\right)\left({ }^{\circ} \mathrm{C}\right) * i
$$

Where $\mathrm{i}$ is the current density of SOFC, $\mathrm{mA} / \mathrm{cm}^{2}$; $\mathrm{T}$ is operating temperature, ${ }^{\circ} \mathrm{C} ; T_{r e f}=1000^{\circ} \mathrm{C}$; At $900 \sim 1050^{\circ} \mathrm{C}$, $\mathrm{K}=8$.

3) Influence of hydrogen /water vapor/ oxygen partial pressure on voltage: The influence of hydrogen/ water vapor/ oxygen partial pressure on the voltage is shown as eqn. (4) (5)below:

$$
\Delta V_{\text {an }}(\mathrm{mV})=172 \log \left(\frac{p_{\mathrm{H}_{2}}}{p_{\mathrm{H}_{2} \mathrm{O}}} /\left(\frac{p_{\mathrm{H}_{2}}}{p_{\mathrm{H}_{2} \mathrm{O}}}\right)_{\text {ref }}\right)
$$

Where $p_{\mathrm{H}_{2}} 、 p_{\mathrm{H}_{2} \mathrm{O}}$ is the average $\mathrm{H}_{2} 、 \mathrm{H}_{2} \mathrm{O}$ partial pressure in anode;

$$
\Delta V_{\text {cat }}(\mathrm{mV})=92 \log \left(p_{\mathrm{O}_{2}} /\left(p_{\mathrm{O}_{2}}\right)_{\text {ref }}\right)
$$

Where $p_{\mathrm{O}_{2}}$ is the average oxygen partial pressure in cathode; $\quad\left(p_{\mathrm{O}_{2}}\right)_{\text {ref }}=0.164$. below:

In summary, the voltage can be obtained as the eqn. (6)

$$
V_{\mathrm{SOFC}}=V_{\mathrm{ref}}+\Delta V_{p}+\Delta V_{T}+\Delta V_{\mathrm{cat}}+\Delta V_{\mathrm{an}}
$$

\section{The Efficiency Model of SOFC}

When using the first law of thermodynamic to evaluate the combined system, we can use SOFC electrical efficiency, electrical efficiency of the overall system, SOFC power, total power ect as the evaluation indexes.

1) SOFC efficiency: The SOFC power and electrical efficiency can be written as follow eqn.(7)(8):

$$
\begin{aligned}
& W_{\text {cell }}=V_{\text {SOFC }} \times I \times 0.92 \\
& \eta_{\text {cell }}=\frac{W_{\text {cell }}}{m_{f} \times Q_{f}} \times 100 \%
\end{aligned}
$$

Where 0.92 is $\mathrm{DC} / \mathrm{AC}$ inverter efficiency;

2) Electrical efficiency of the overall system: The electrical efficiency of the combined system can be defined as eqn. (9):

$$
\eta_{c c}=\frac{W_{c e l l}+W_{g t}+W_{s t}-W_{C 1}-W_{C 2}-W_{P U M P 1}-W_{P U M P 2}}{m_{f} \cdot Q_{f}} \times 100 \%
$$

\section{RESULTS AND ANALYSIS}

\section{A Performance Analysis of Specific Condition}

\begin{tabular}{|c|c|c|c|}
\hline Parameters & Values & Parameters & Values \\
\hline $\begin{array}{c}\text { SOFC } \\
\text { current } \\
\text { density/ } \\
\mathrm{A} / \mathrm{m}^{2}\end{array}$ & 2393.9 & $\begin{array}{c}\text { Pump 1 } \\
\text { power/ kW }\end{array}$ & 2.61 \\
\hline $\begin{array}{c}\text { SOFC } \\
\text { operating } \\
\text { voltage/ V }\end{array}$ & 0.714 & $\begin{array}{c}\text { Pump } 2 \\
\text { power / kW }\end{array}$ & 0.34 \\
\hline $\begin{array}{c}\text { SOFC } \\
\text { operating } \\
\text { temperature/ } \\
\mathrm{K}\end{array}$ & 1173 & $\begin{array}{c}\mathrm{AT} \\
\text { temperature/ } \\
\mathrm{K}\end{array}$ & 649.1 \\
\hline $\begin{array}{c}\text { Fuel } \\
\text { compressor } \\
\text { power/ kW }\end{array}$ & 33.03 & $\begin{array}{c}\text { GT power/ } \\
\text { kW }\end{array}$ & 1016.41 \\
\hline $\begin{array}{c}\text { Air } \\
\text { compressor } \\
\text { power } / \mathrm{kW}\end{array}$ & 537.06 & $\begin{array}{l}\text { ST power/ } \\
\text { kW }\end{array}$ & 139.88 \\
\hline $\begin{array}{c}\text { SOFC } \\
\text { electrical } \\
\text { power/ kW }\end{array}$ & 1510.15 & $\begin{array}{c}\text { Net power/ } \\
\text { kW }\end{array}$ & 2093.39 \\
\hline $\begin{array}{c}\text { SOFC } \\
\text { electrical } \\
\text { efficiency } \\
/ \%\end{array}$ & 53.7 & $\begin{array}{c}\text { Electrical } \\
\text { efficiency } \\
\text { of the } \\
\text { system } / \%\end{array}$ & 74.46 \\
\hline
\end{tabular}

In this article, we use Aspen Plus for simulation. The fuel includes $97 \%$ of $\mathrm{CH}_{4}$ and $3 \%$ of $\mathrm{N}_{2}$. Kalina cycle is used as a bottom loop for further recovery of exhaust heat from GT. Through further analysis by the first law of thermodynamics we can obtain system performance indexes as shown in Table 1.

TABLEI. PERFORMANCE INDEXES OF SOFC-GT-KALINA CYCLE SYSTEM

From the result, we can see that the proposed system has high efficiency.

B Influence of Compressor Pressure Ratio on the Integrated System

Figure 2 (a) and (b) respectively shows the effects of compressor pressure ratio on system electrical power and efficiency.

As can be seen from Figure 2(a), SOFC power is the most important part of all, SOFC power and GT power increase with the pressure ratio increase, when the pressure ratio increases from 4 to 10 , SOFC power changes from $1368.96 \mathrm{~kW}$ to $1510.15 \mathrm{~kW}$, GT power changes from 
$675.18 \mathrm{~kW}$ to $1016.41 \mathrm{~kW}$. This is due to at higher operating pressure, the electrochemical reaction is carried out more completely; ST power decreases with the pressure ratio increases, which takes a small proportion of the total, the main reason is increasing the pressure ratio will reduce the exhaust gas temperature, the thermal load which can be provided to Karina cycles decreases slightly, it will lead to ST power decrease.

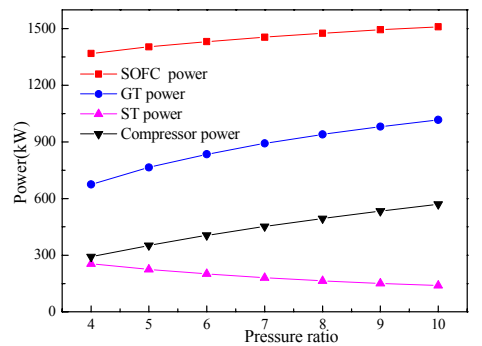

(a)

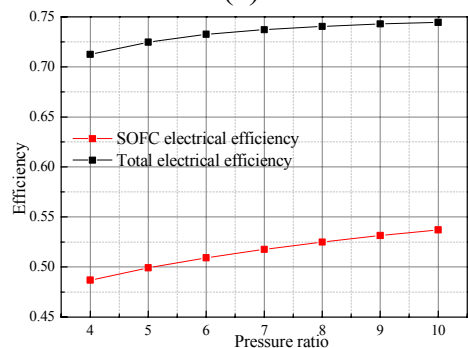

(b)

FIGURE II. EFFECTS OF COMPRESSOR PRESSURE RATIO ON SYSTEM ELECTRICAL POWER AND EFFICIENCY

As shown in Figure 2(b) SOFC electrical efficiency and overall system electrical efficiency both increases with pressure ratio increase. When the pressure ratio increases from 4 to 10 , SOFC electrical efficiency changes from $48.69 \%$ to $53.72 \%$, overall electrical efficiency changes from $71.26 \%$ to $74.46 \%$.

In summary, if the pressure ratio is too small, it is not good for system performance. When the pressure is too large, it needs higher requirement on the material and equipment, and poor economic performance, so when selecting pressure, we should comprehensively considered.

\section{Influence of Ammonia Flow on the Integrated System}

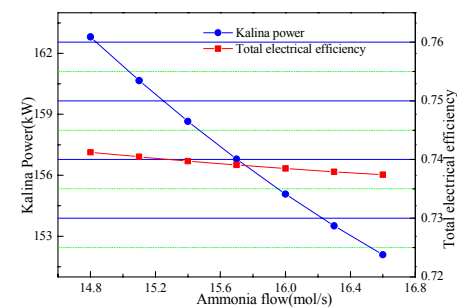

(a)

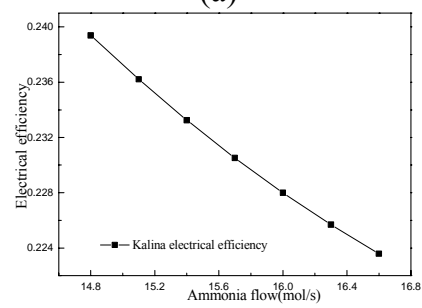

(b)

FIGURE III. EFFECTS OF AMMONIA FLOW ON KALINA POWER AND TOTAL ELECTRICAL EFFICIENCY
When the exhaust parameters maintain constant, the heat supplied to Kalina is unchanged. Figure 3(a) shows the effect of ammonia flow on Kalina power and total electrical efficiency. Figure 3(b) shows the effect of ammonia flow on Kalina electrical efficiency.

As can be seen from the figure, Kalina power and electrical efficiency declines with the ammonia flow increase, this is due to the increase of ammonia flow will reduce the temperature of superheated steam through the ST; The total electrical efficiency of the system slightly decreases with the increasing of ammonia flow rate, but just a very little scope. This is due to in the integrated system, ST power takes a very small proportion, so the influence on the whole system is little.

In summary, when the heat load is constant, if the ammonia flow is too small, since the heating temperature limited by the exhaust gas temperature, working fluid cannot be heated to a too high temperature, which can result inadequate utilization of waste heat; When the ammonia flow is too large, ST inlet temperature will be reduced, it is not good for ST working. Therefore, every time changing operating condition, we should adjust the flow rate to make the temperature appropriable.

D Influence of ST inlet pressure and ammonia concentration on the system

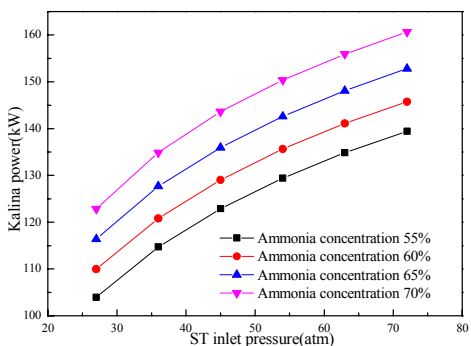

(a)

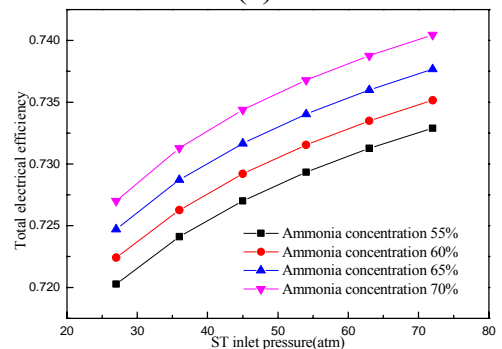

(b)

FIGURE IV. EFFECTS OF ST INLET PRESSURE ON KALINA POWER AND TOTAL ELECTRICAL EFFICIENCY

Figure 4 shows the effect of ST inlet pressure on Kalina power and the electrical efficiency of the integrated system under different ammonia concentration respectively. From figure (a) we can see that Kalina cycle power increases with ST inlet pressure increase, also increases with ST ammonia concentration increase. This is due to ST inlet pressure can influence the enthalpy drop between import and export of gas turbine. When ammonia concentration increases, the boiling point of mixture decreases, the amount of ammonia vapor evaporated increases, resulting the increase of ST power; As can be seen from (b), the total electrical efficiency of the integrated system slightly increases with ST inlet pressure increase, the total electrical efficiency of the integrated system slightly increases with ammonia concentration increase. 
Therefore, in order to make the system run more efficiently, we should reasonably increase the ammonia concentration and ST inlet pressure in a certain range. However, due to excessive pressure will need high requirement on material, the pressure shouldn't be too high; Because ammonia is corrosive and difficult to control, if the ammonia concentration is too high it will have close properties with pure substances and will lost the characteristics of evaporation temperature change, the concentration should not be too high.

\section{CONCLUSION}

Nowadays high-efficient thermodynamic cycle systems is drawing more and more attention, in this article, we use Aspen Plus for the SOFC-GT-Kalina integrated system simulation and do performance analysis by the first law of thermodynamics, the main conclusions we can draw are as follows:

(1) Under the given conditions, SOFC power generation efficiency is $53.7 \%$, the overall electrical efficiency can reach $74.46 \%$, this can prove the high efficiency of the system;

(2) Increasing the compression ratio helps to improve the performance of the system, SOFC electrical efficiency and the electrical efficiency of the overall system both increases with the pressure ratio increases.

(3) When the heat load is constant, we should adjust suitable ammonia flow rate to make the temperature appropriable.

(4) In order to make the system run more efficiently, we should reasonably increase the ammonia concentration and $\mathrm{ST}$ inlet pressure in a certain range.

The results of energy analysis have a guiding role on the SOFC-GT-Kalina combined cycle system design and optimization.

\section{ACKNOWLEDGMENTS}

The Project Supported by National Natural Science Foundation of China No. 51274224.

\section{REFERENCE}

[1] Hao Cai, Jieying Chen, Kui Deng, The solid oxide cell system and its application [J]. Contemporary Chemical Industry, 43(7), pp.1261-1263,2014.

[2] Qimei Chen, Yiwu Weng, Shilie Weng, The hybrid power system combined of high temperature fuel cell and gas turbine[J]. Thermal Power Engineering, 20(2), pp. 111-115, 2005.

[3] Komatsu Y, Kimijima S, Szmyd J S, Performance analysis for the part-load operation of a solid oxide fuel cell-micro gas turbine hybrid system. Energy, 35, pp. 982-988, 2010.

[4] Alexandros A., Thermo economic Modeling and Parametric Study of Hybrid SOFC-Gas Turbine-Steam Turbine Power Plants Ranging from 1.5 to 10MW. Journal of power sources, 181, pp. 313-326, 2008.

[5] Juxing Song. Prospect of Solid Oxide Fuel Cell, 2009.

[6] Liansuo An, Jian Zhang, Hui Ma, Cogeneration System Of Solid Oxide Fuel Cell and Gas Turbine. Renewable Energy Resources, 26(1), 2008.

[7] Xiaoru Chen, The introduction of a new kind of thermodynamic cycle-Kalina cycle [J]. Shanghai Electric Power, 8(3): 8-10, 1995. 